\title{
An Imine Photocyclization as an Alternative to the Pictet-Spengler Reaction for the Synthesis of AzaBenzannulated Perylenediimide Dyes
}

\author{
Antoine Goujon,* Lou Rocard, Thomas Cauchy and Piétrick Hudhomme.* \\ Laboratoire MOLTECH-Anjou, UMR CNRS 6200, UNIV Angers, SFR MATRIX,2 Bd \\ Lavoisier, ANGERS Cedex, 49045 France \\ antoine.goujon@univ-angers.fr \\ pietrick.hudhomme@univ-angers.fr
}




\section{Table of Contents}

$\begin{array}{lll}\text { 1. Electrochemistry } & \text { S3 }\end{array}$

2. Calculations $\quad$ S4

3. NMR S4

4. Mass Spectrometry $\quad$ S12 


\section{Electrochemistry}

Cyclic voltammetry was carried out on a Bio-Logic SAS SP-150 potentiostat with a three electrodes configuration, using a silver wire as $\mathrm{Ag} / \mathrm{AgCl}$ reference electrode, a $\mathrm{Pt}$ wire as counter electrode, and a Pt electrode as working electrode. Samples $\left(\mathrm{C}=5.10^{-4} \mathrm{M}\right)$ were dissolved in a $0.1 \mathrm{M} \mathrm{Bu}_{4} \mathrm{NPF}_{6}$ solution in $\mathrm{CH}_{2} \mathrm{Cl}_{2}$ as supporting electrolyte and ferrocene was used as internal reference. The scan rate is $100 \mathrm{mV} . \mathrm{s}^{-1}$. The solutions were degassed by bubbling argon for $30 \mathrm{~s}$ before measurements.

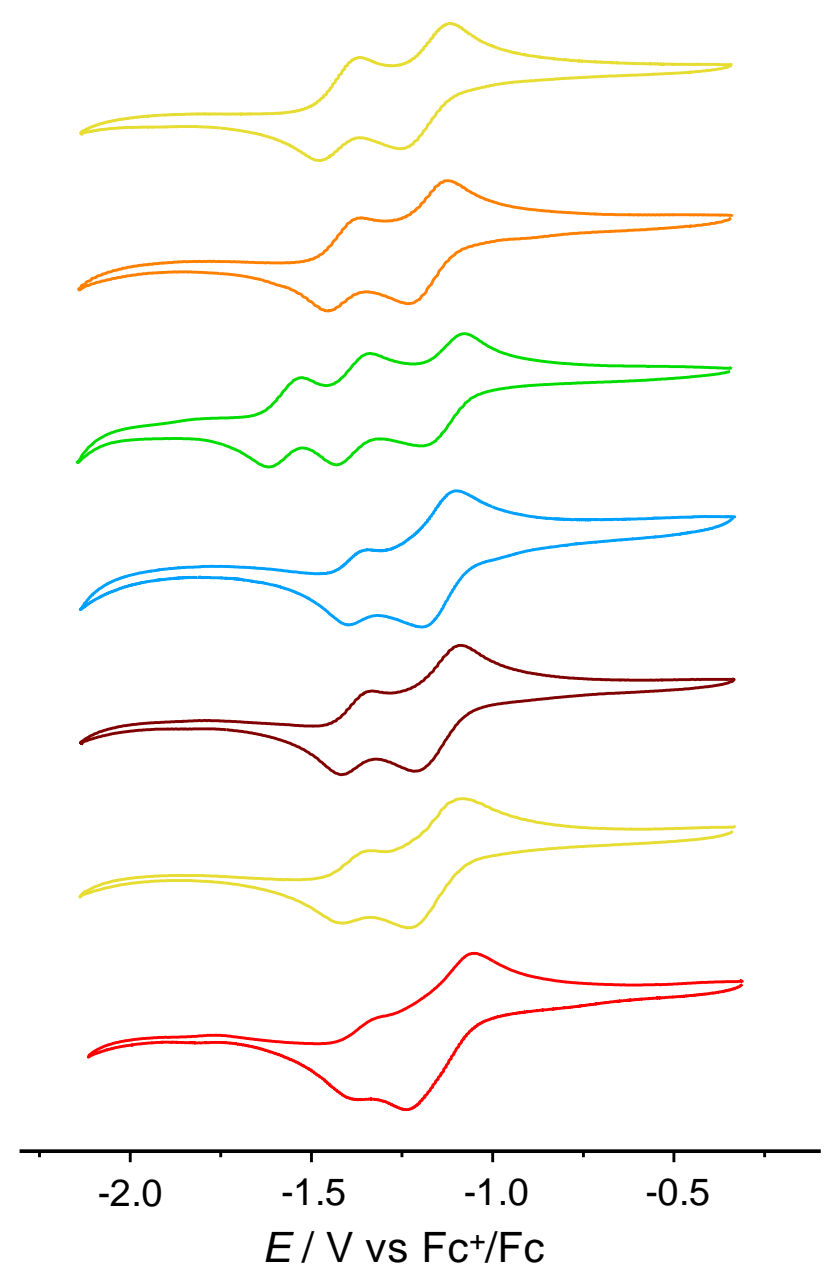

Figure S1. Cyclic voltammogram of compound 1, 2, 3, 4, 5, 6 and 7 (in that order from top to bottom). $\mathrm{V} v s \mathrm{Fc}^{+} / \mathrm{Fc}$. 


\section{Calculations}

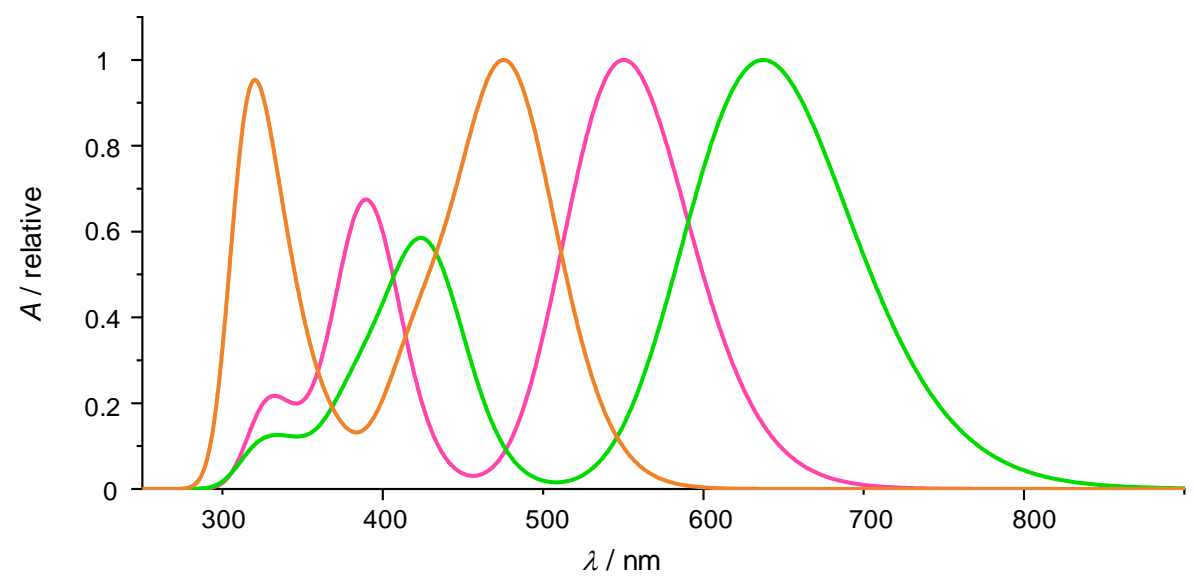

Figure S2. Simulated UV-Visible absorption spectra obtained from DFT calculations for compound 1 (orange), 1i (purple) and 1c (green). Details of calculations can be found in the Molecular Calculation Report available alongside this manuscript.

\section{NMR}

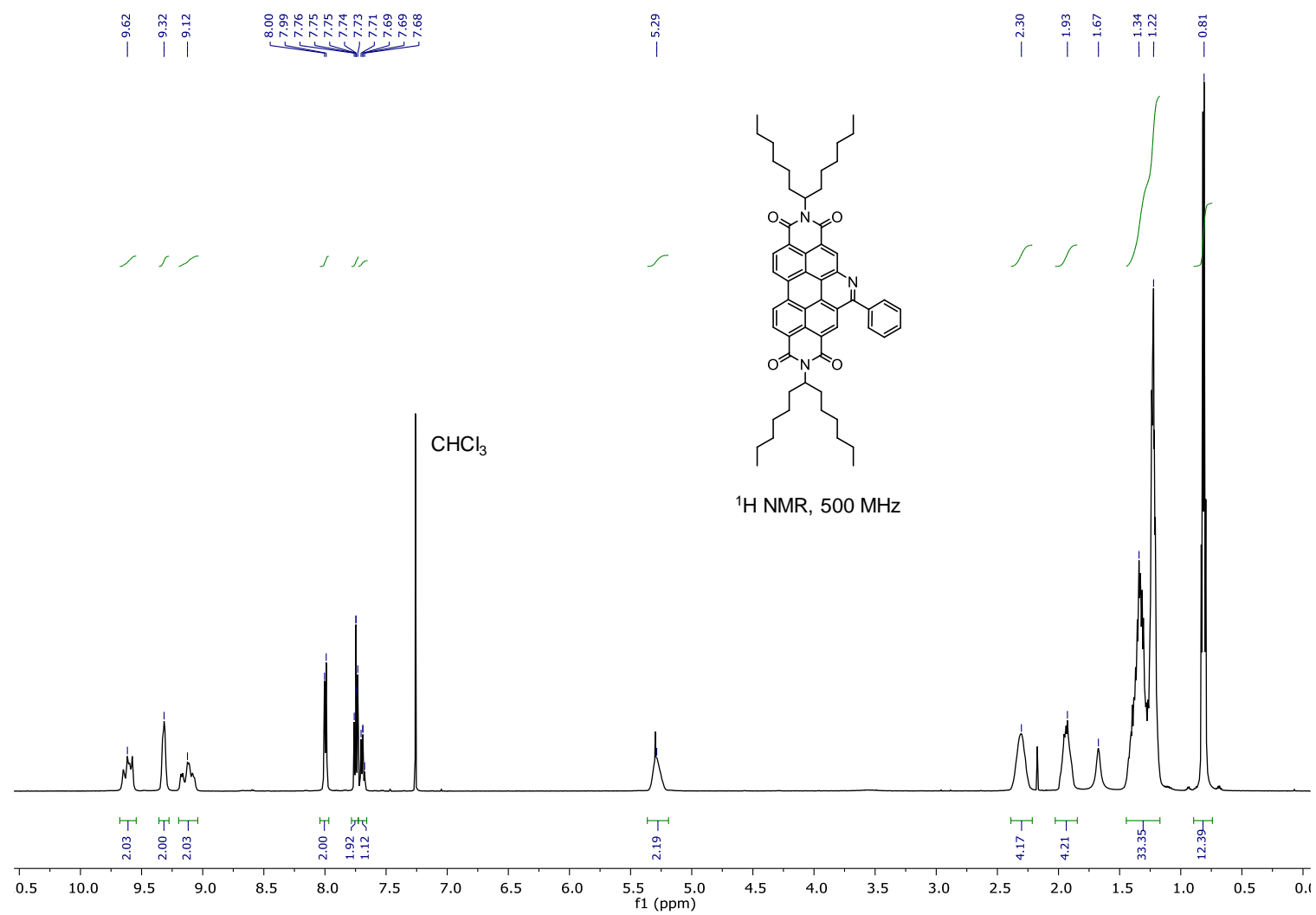

Figure S3. ${ }^{1} \mathrm{H}$ NMR spectrum of compound $\mathbf{1}$ in $\mathrm{CDCl}_{3}$ at $298 \mathrm{~K}$. 

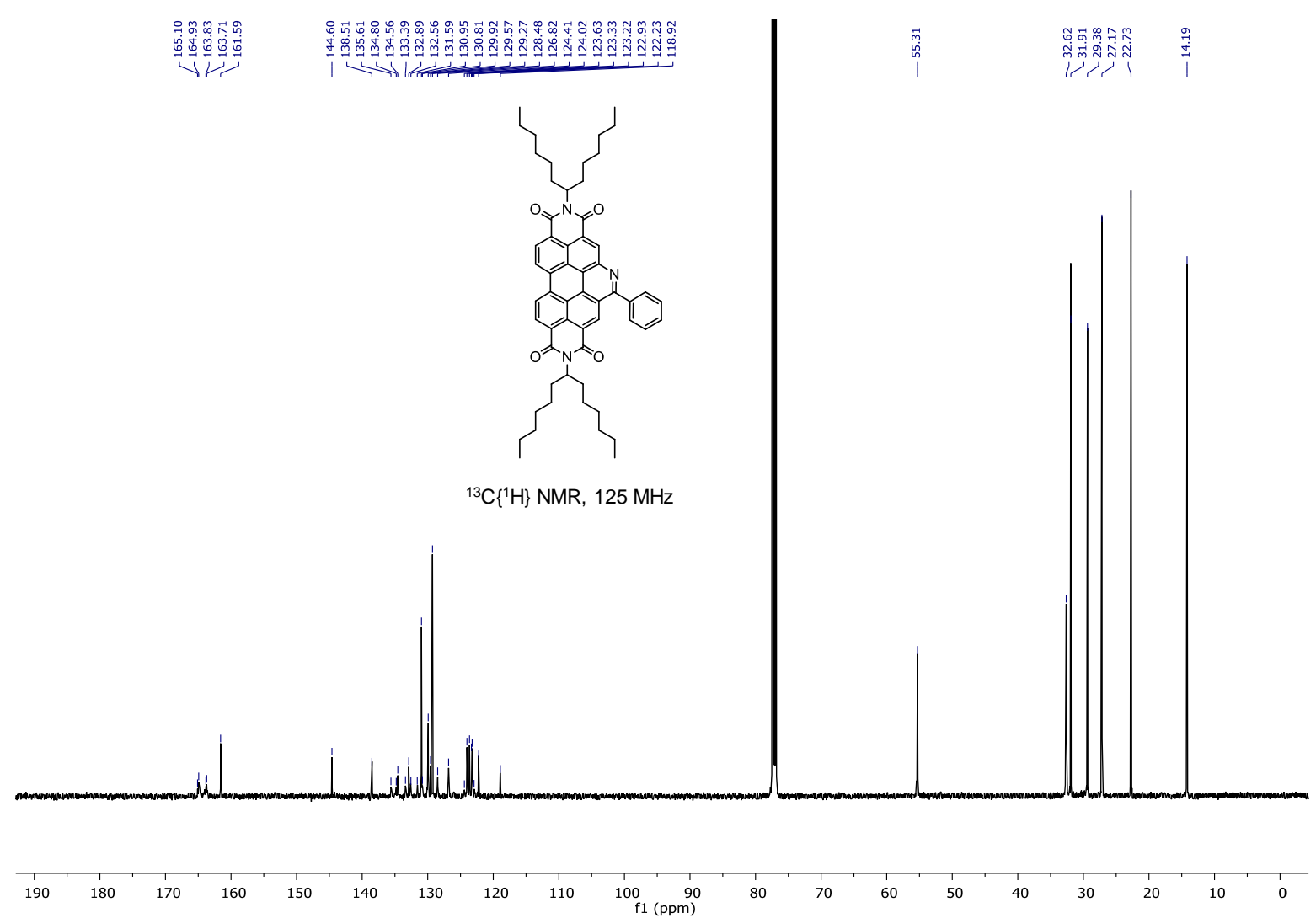

Figure S4. ${ }^{13} \mathrm{C}\left\{{ }^{1} \mathrm{H}\right\}$ NMR spectrum of compound 1 in $\mathrm{CDCl}_{3}$ at $289 \mathrm{~K}$.

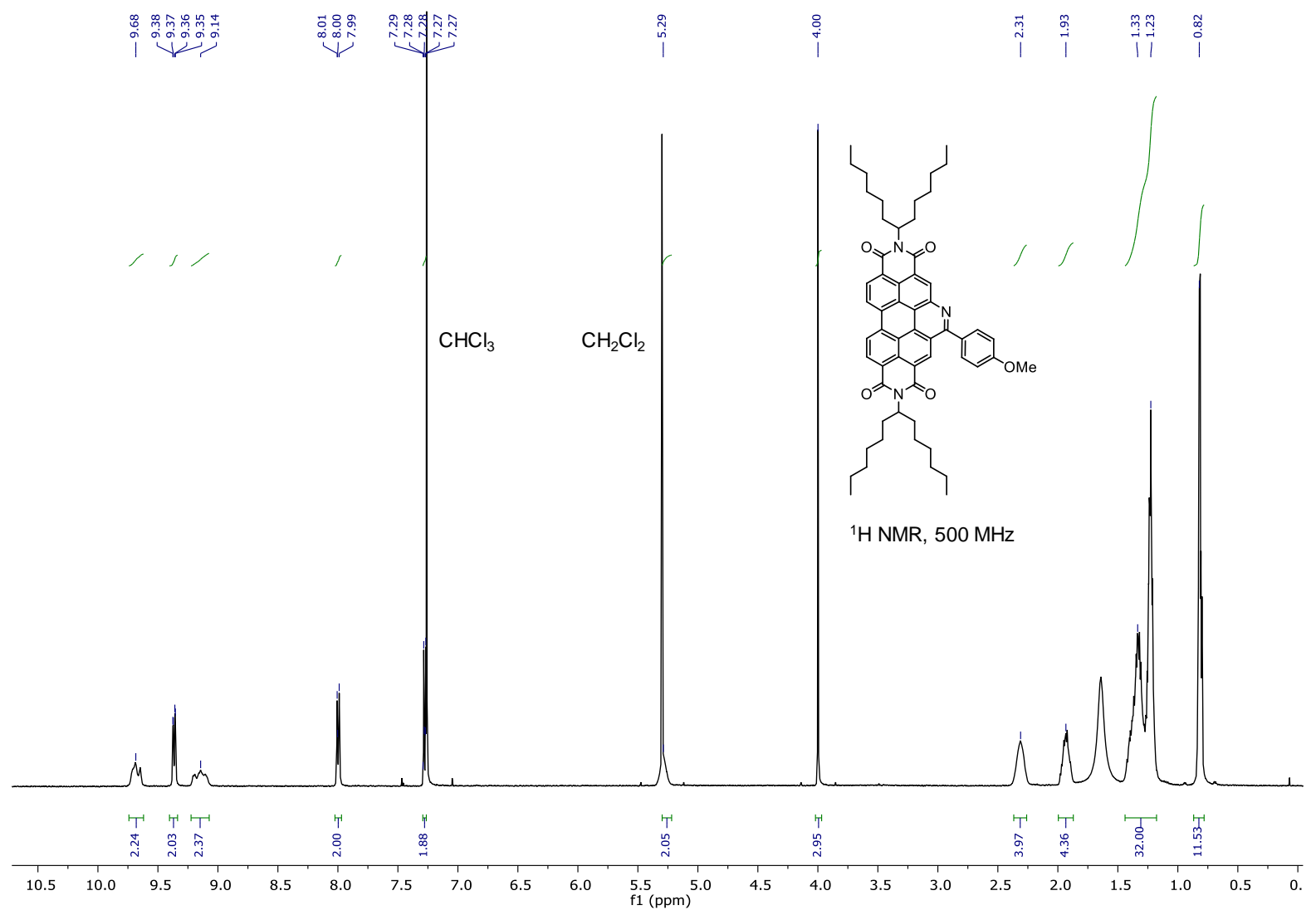

Figure S5. ${ }^{1} \mathrm{H}$ NMR spectrum of compound 2 in $\mathrm{CDCl}_{3}$ at $298 \mathrm{~K}$. 


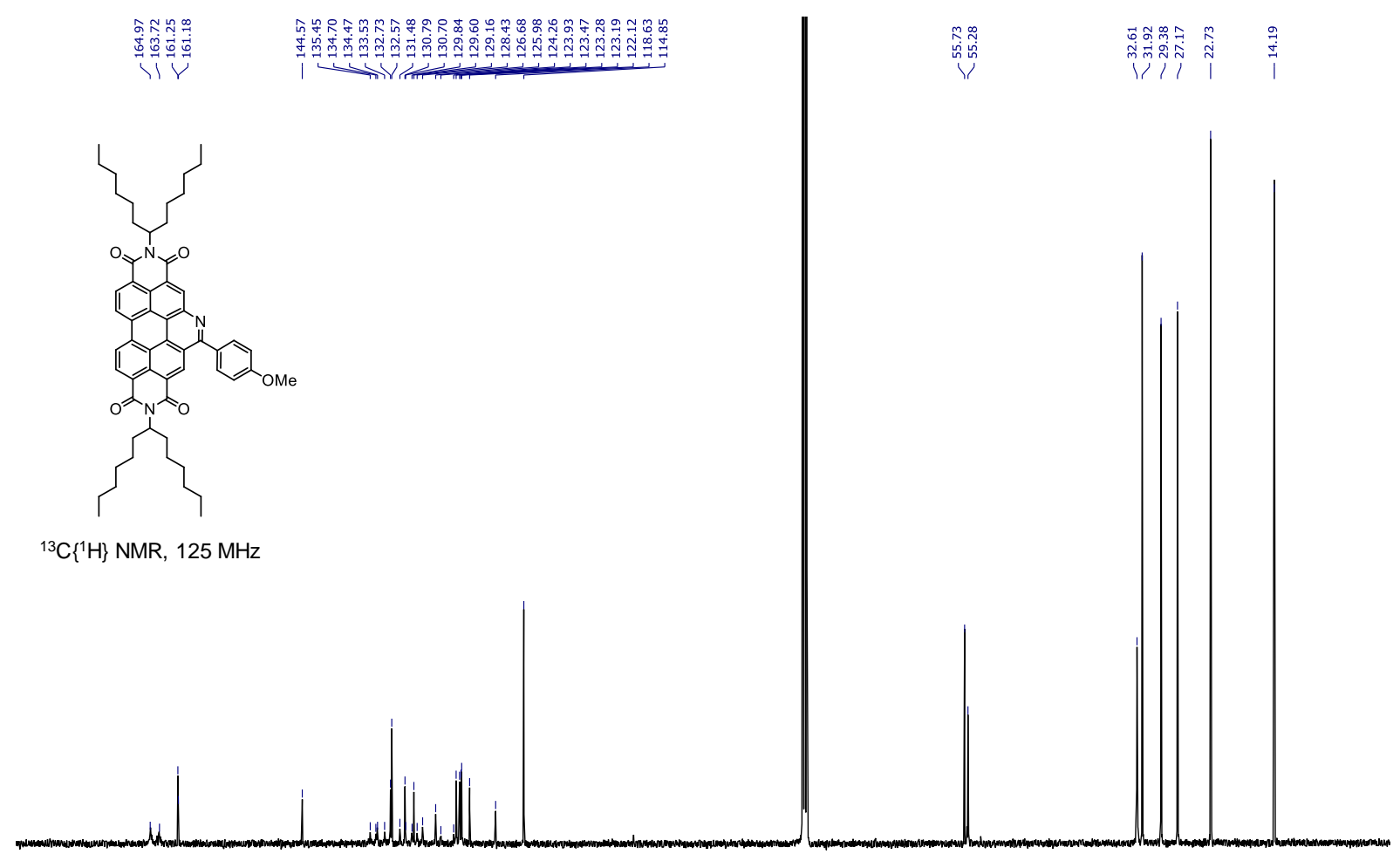

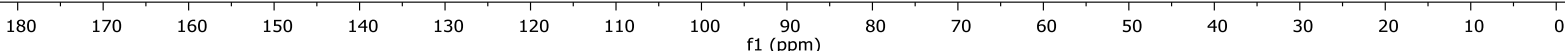

Figure S6. ${ }^{13} \mathrm{C}\left\{{ }^{1} \mathrm{H}\right\}$ NMR spectrum of compound $\mathbf{2}$ in $\mathrm{CDCl}_{3}$ at $298 \mathrm{~K}$.

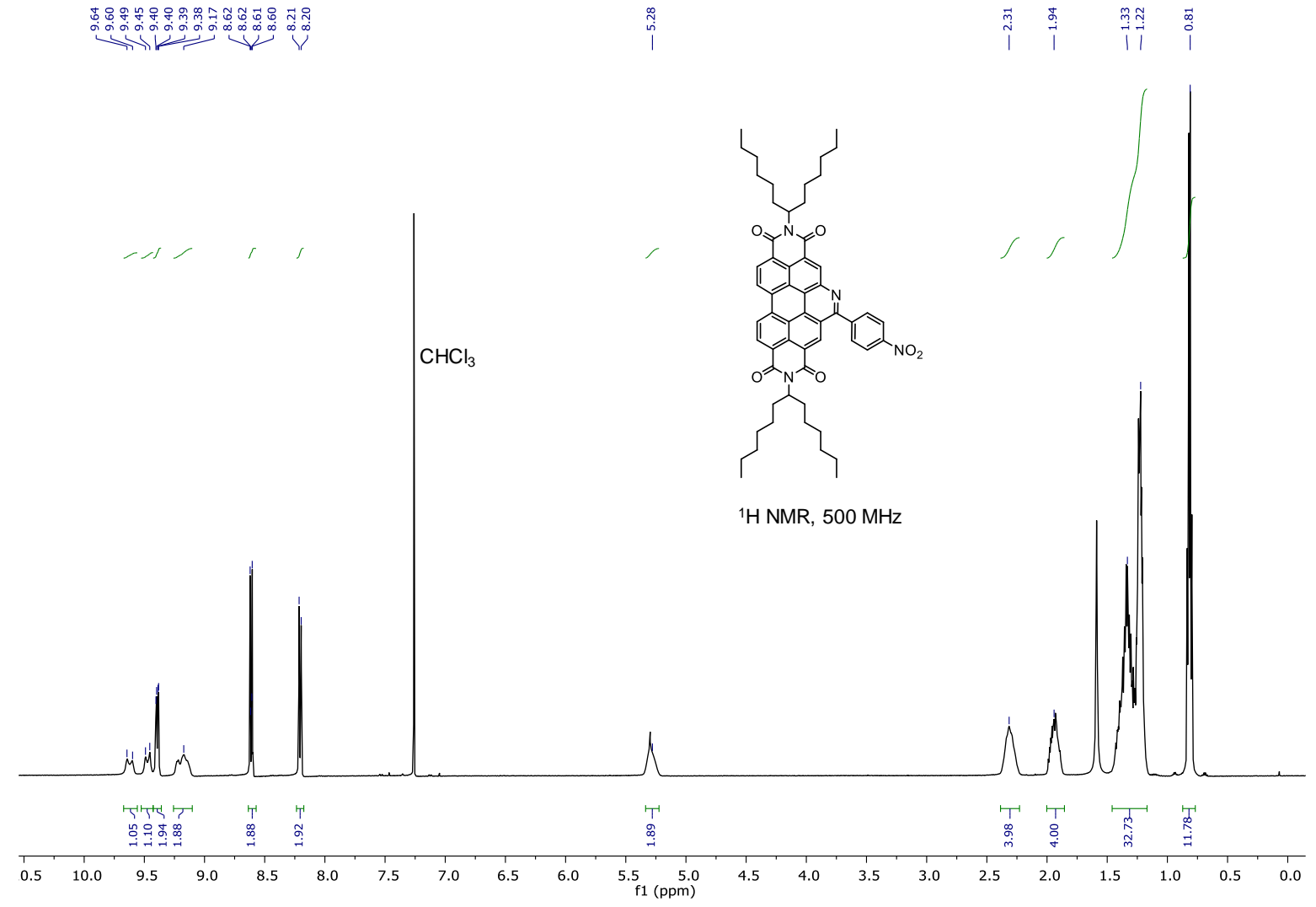

Figure S7. ${ }^{1} \mathrm{H}$ NMR spectrum of compound $\mathbf{3}$ in $\mathrm{CDCl}_{3}$ at $298 \mathrm{~K}$. 

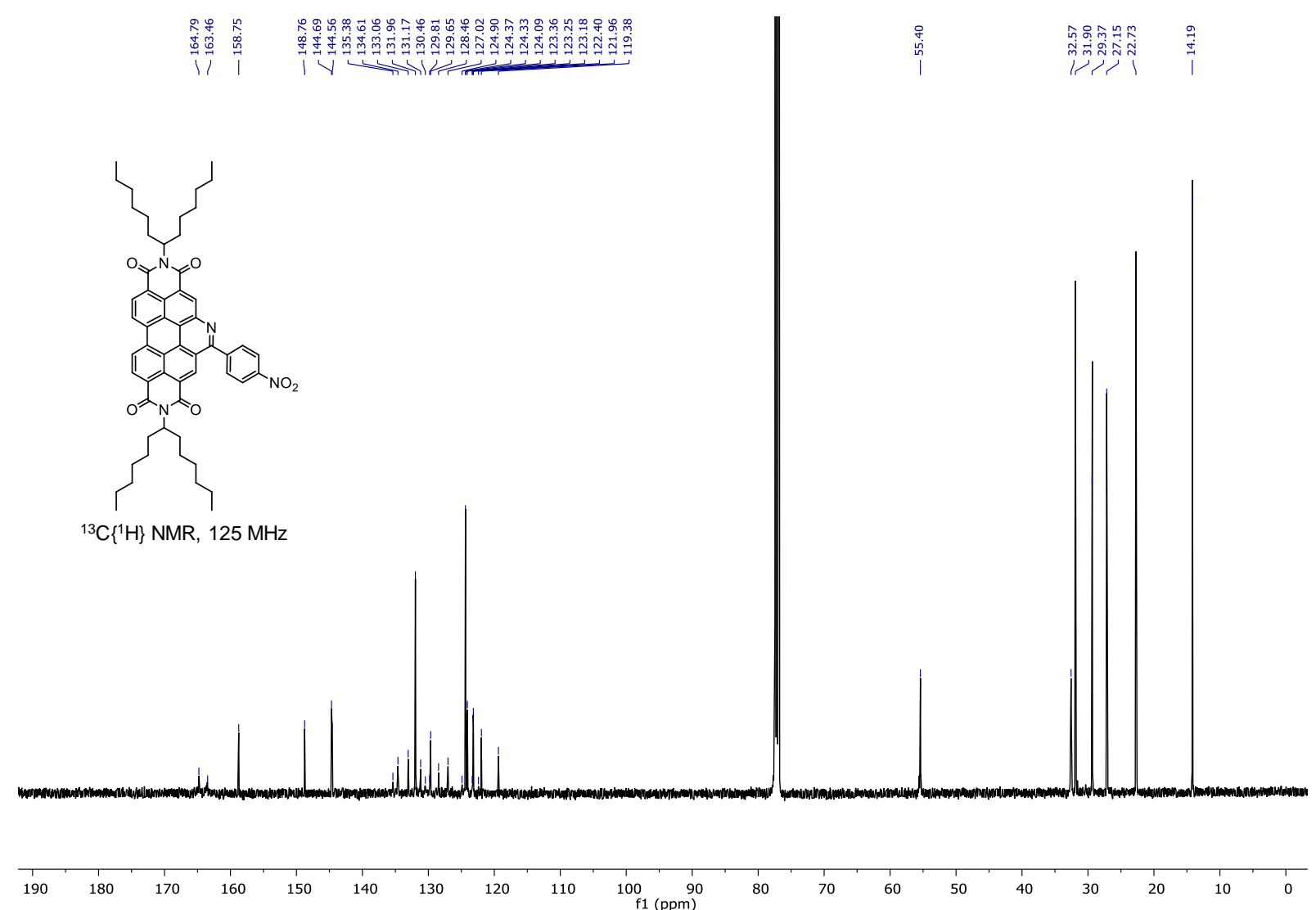

Figure S8. ${ }^{13} \mathrm{C}\left\{{ }^{1} \mathrm{H}\right\}$ NMR spectrum of compound 3 in $\mathrm{CDCl}_{3}$ at $298 \mathrm{~K}$.

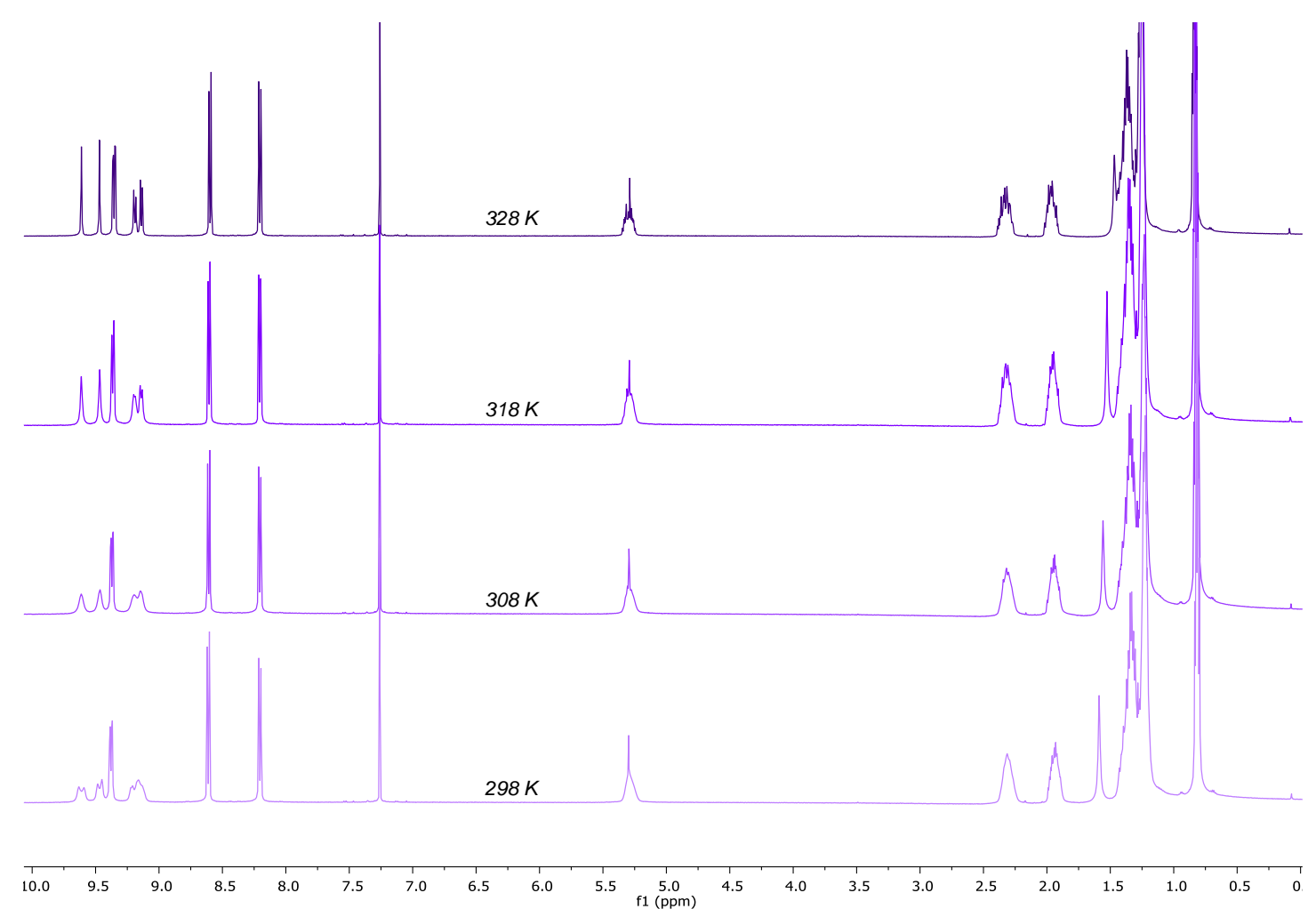

Figure S9. VT ${ }^{1} \mathrm{H}$ NMR spectra of compound 3 in $\mathrm{CDCl}_{3}$ from 298 to $328 \mathrm{~K}$. 


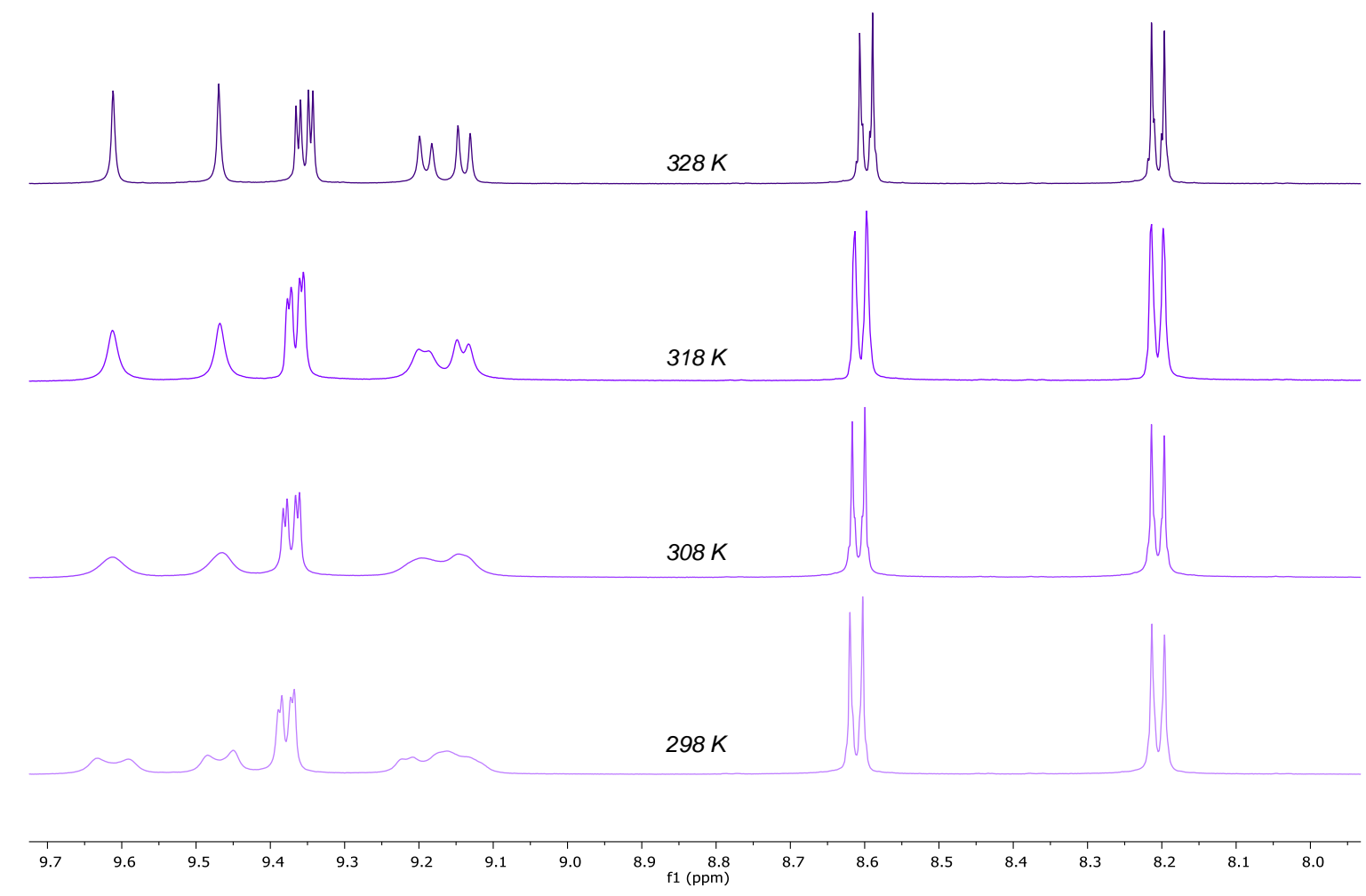

Figure S10. VT ${ }^{1} \mathrm{H}$ NMR spectra of compound 3 in $\mathrm{CDCl}_{3}$ from 298 to $328 \mathrm{~K}$, zoomed on the aromatic region.

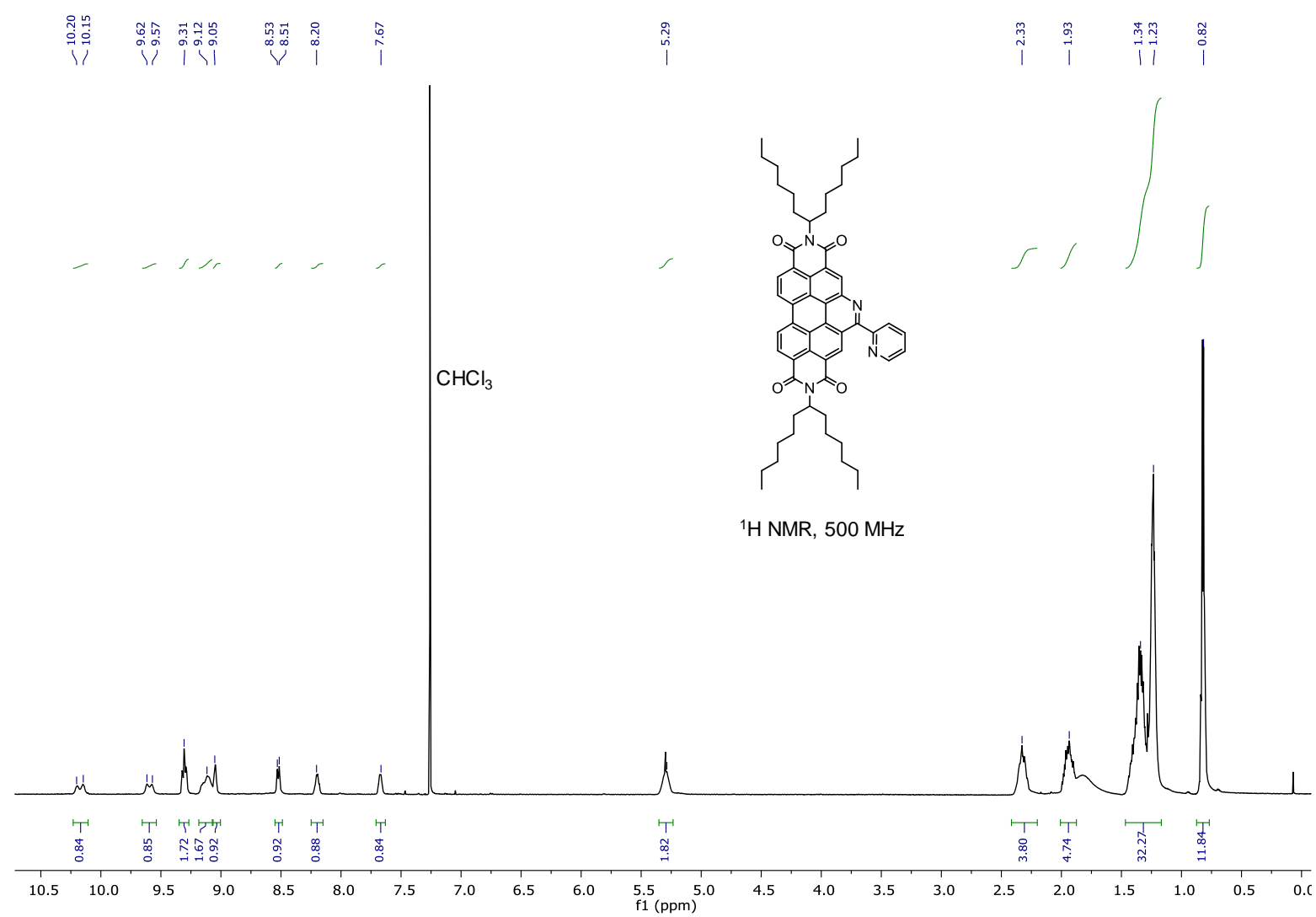

Figure S11. ${ }^{1} \mathrm{H}$ NMR spectrum of compound 4 in $\mathrm{CDCl}_{3}$ at $298 \mathrm{~K}$. 


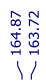

吾

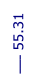

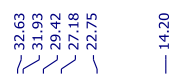

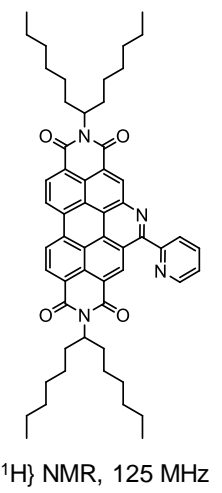

${ }^{13} \mathrm{C}\left\{{ }^{1} \mathrm{H}\right\} \mathrm{NMR}, 125 \mathrm{MHz}$
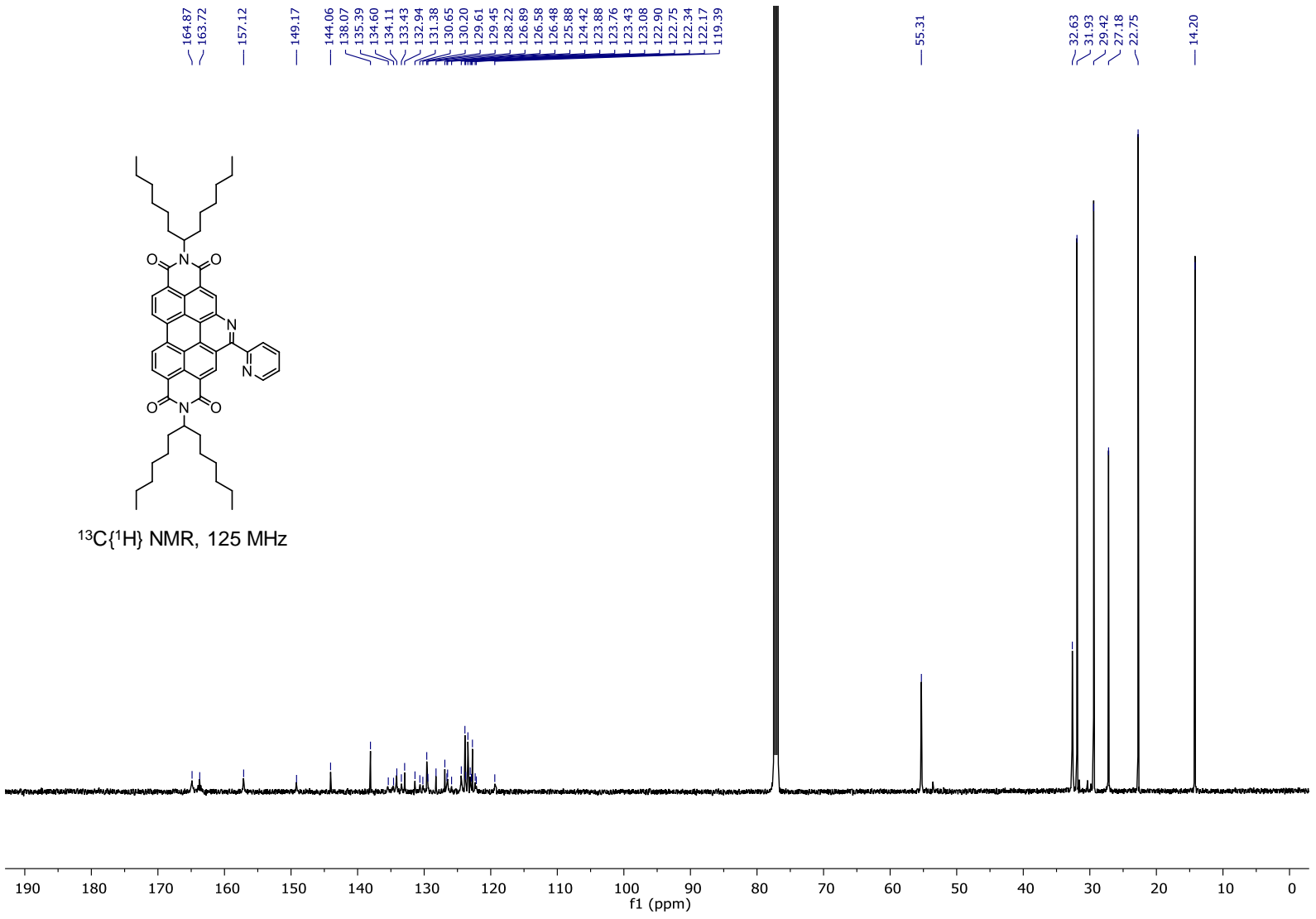

Figure S12. ${ }^{13} \mathrm{C}\left\{{ }^{1} \mathrm{H}\right\}$ NMR spectrum of compound 4 in $\mathrm{CDCl}_{3}$ at $298 \mathrm{~K}$.

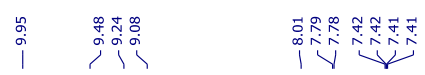
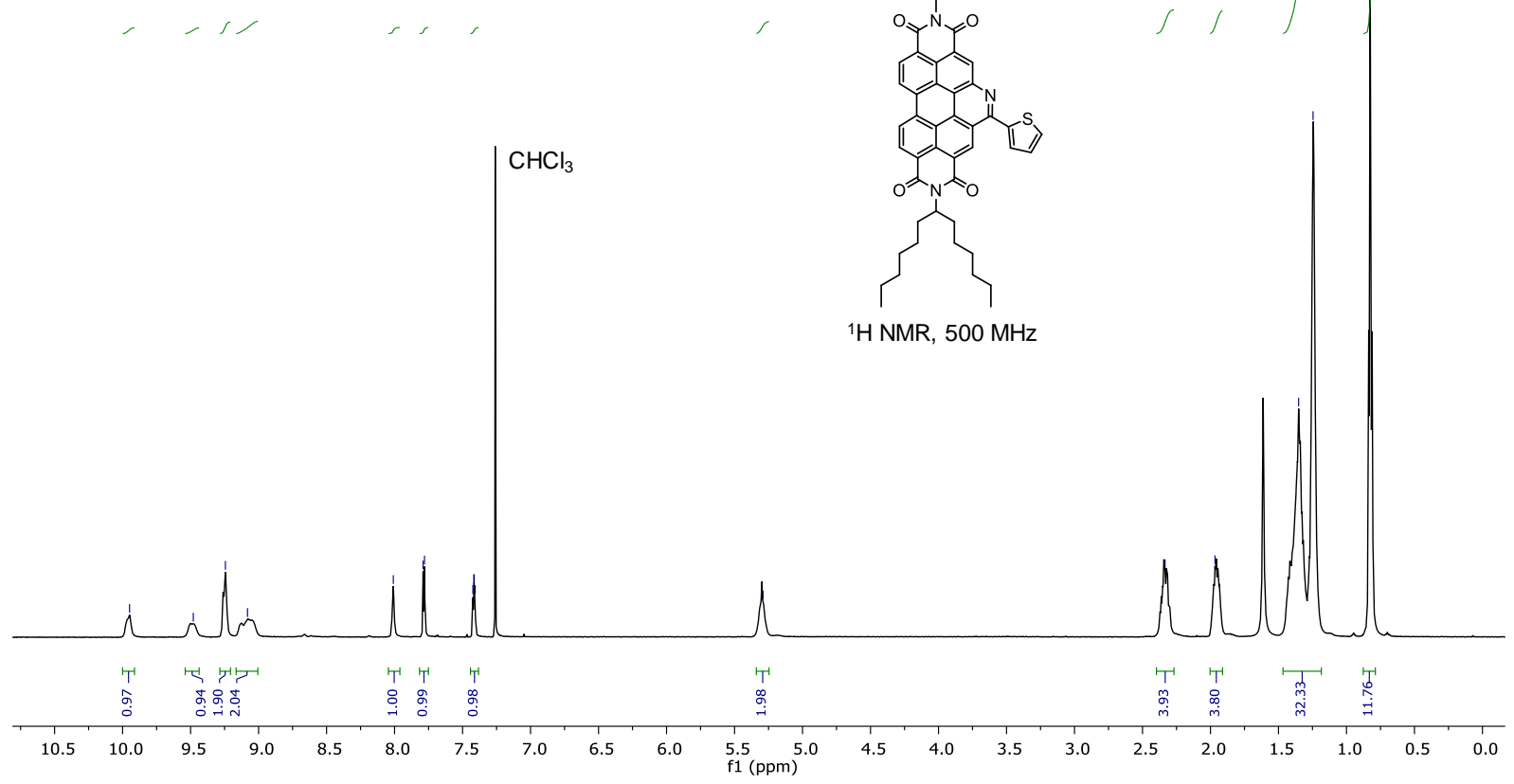

Figure S13. ${ }^{1} \mathrm{H}$ NMR spectrum of compound 5 in $\mathrm{CDCl}_{3}$ at $298 \mathrm{~K}$.

Sq 


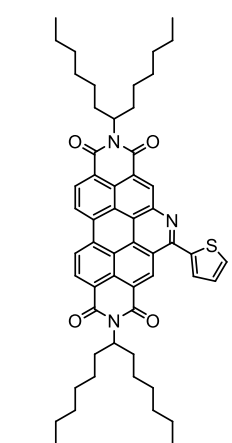

${ }^{13} \mathrm{C}\left\{{ }^{1} \mathrm{H}\right\} \mathrm{NMR}, 125 \mathrm{MHz}$

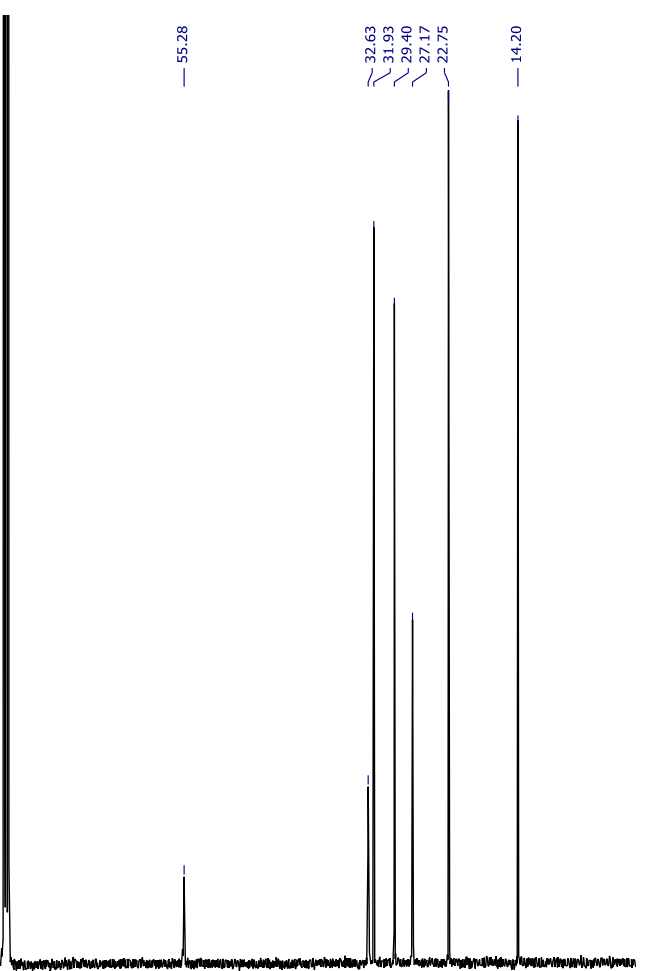

Figure S14. ${ }^{13} \mathrm{C}\left\{{ }^{1} \mathrm{H}\right\}$ NMR spectrum of compound 5 in $\mathrm{CDCl}_{3}$ at $298 \mathrm{~K}$.

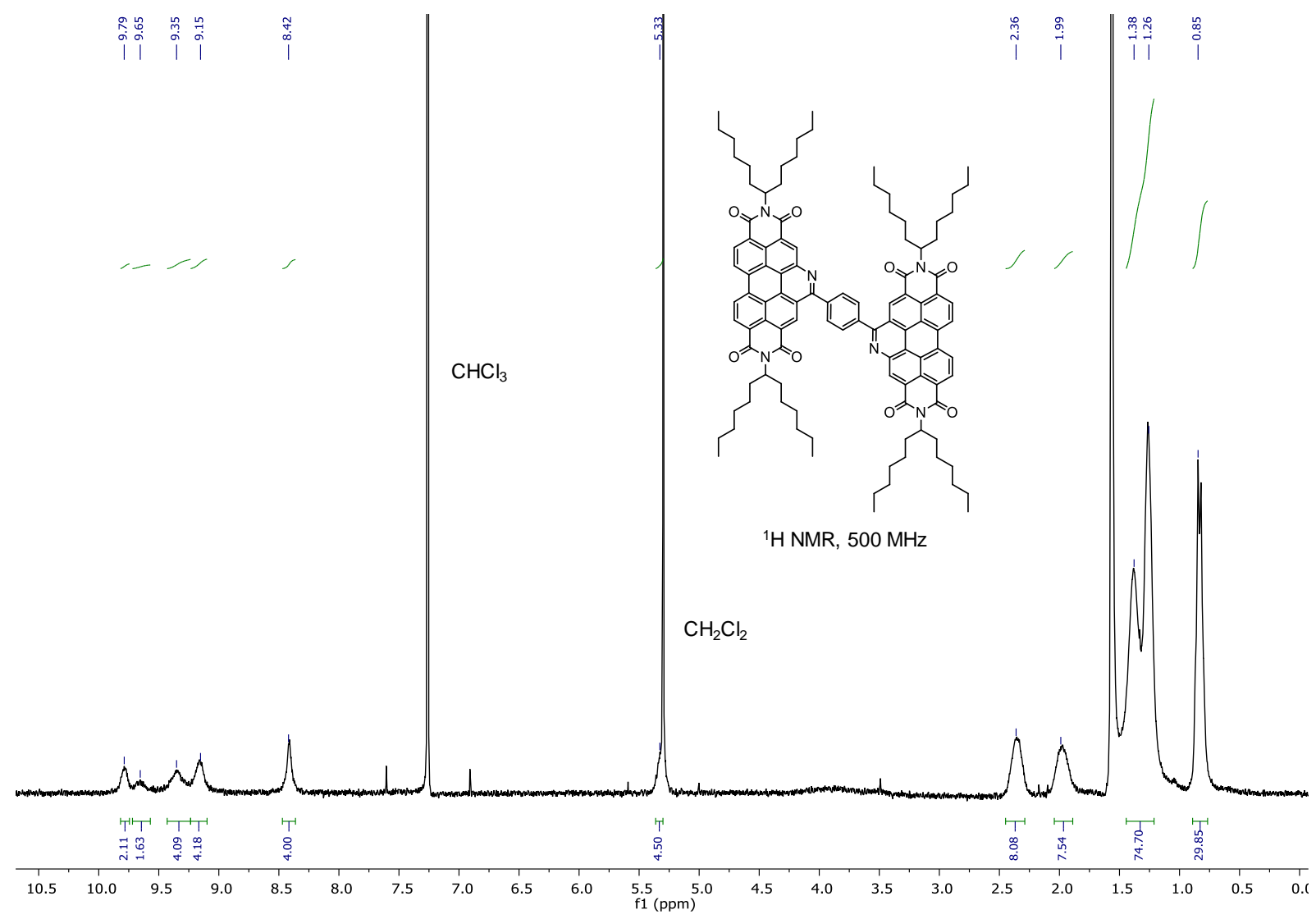

Figure S15. ${ }^{1} \mathrm{H}$ NMR spectrum of compound 6 in $\mathrm{CDCl}_{3}$ at $298 \mathrm{~K}$. 


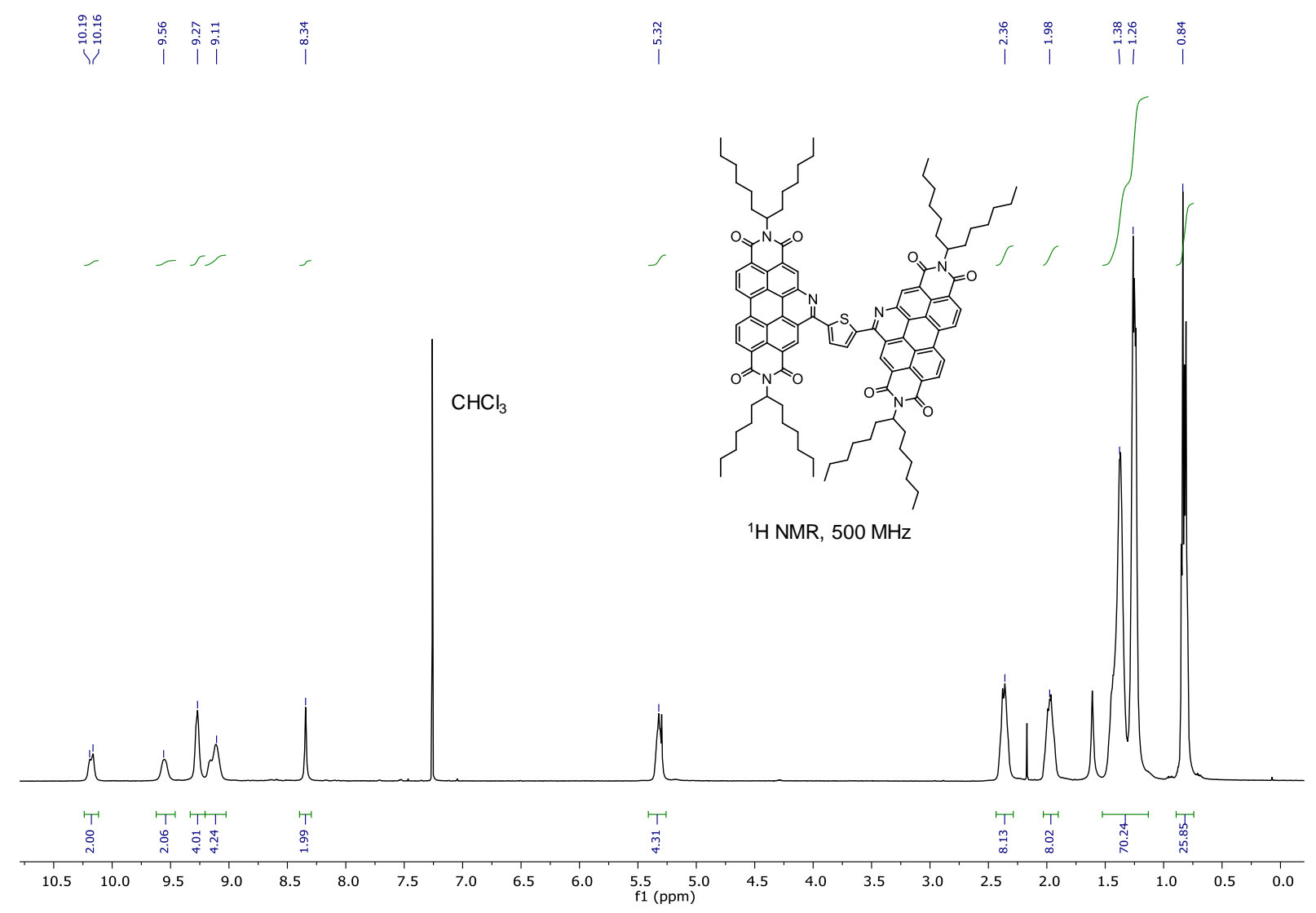

Figure S16. ${ }^{1} \mathrm{H}$ NMR spectrum of compound 7 in $\mathrm{CDCl}_{3}$ at $298 \mathrm{~K}$.

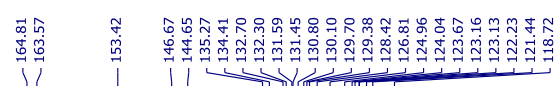

1111 1 11

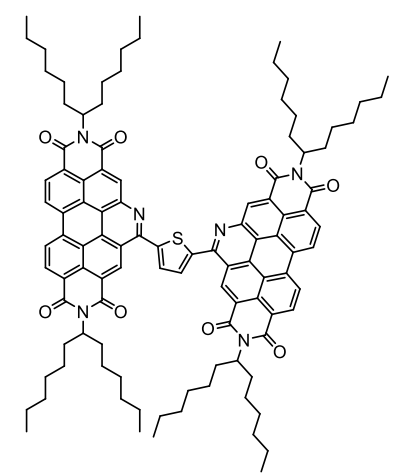

${ }^{13} \mathrm{C}\left\{{ }^{1} \mathrm{H}\right\} \mathrm{NMR}, 125 \mathrm{MHz}$

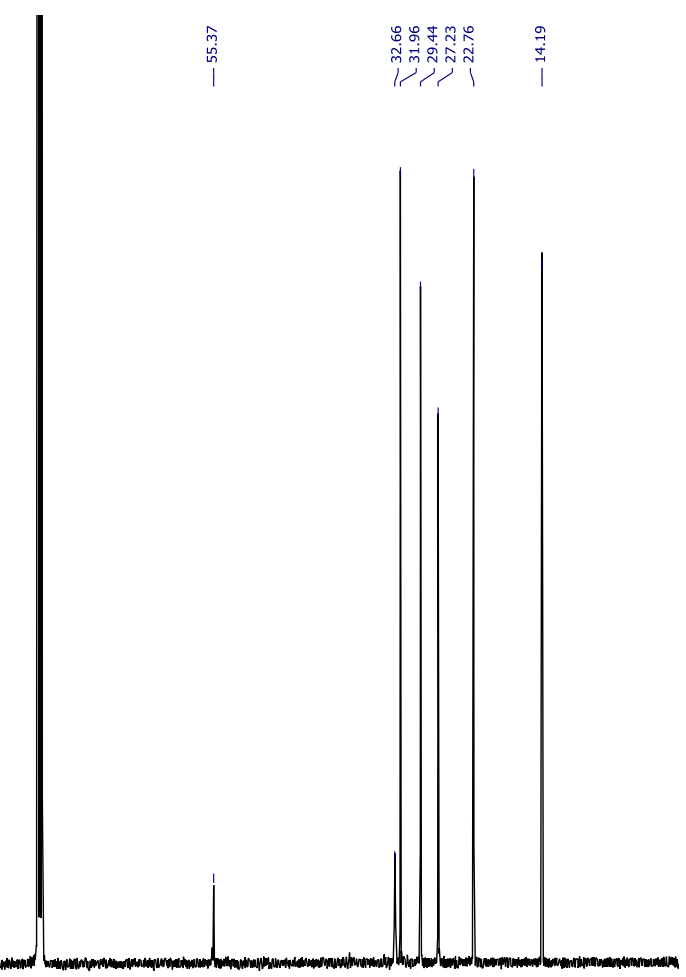

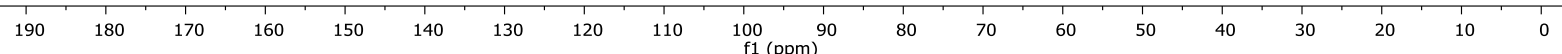

Figure S17. ${ }^{13} \mathrm{C}\left\{{ }^{1} \mathrm{H}\right\}$ NMR spectrum of compound 7 in $\mathrm{CDCl}_{3}$ at $298 \mathrm{~K}$. 


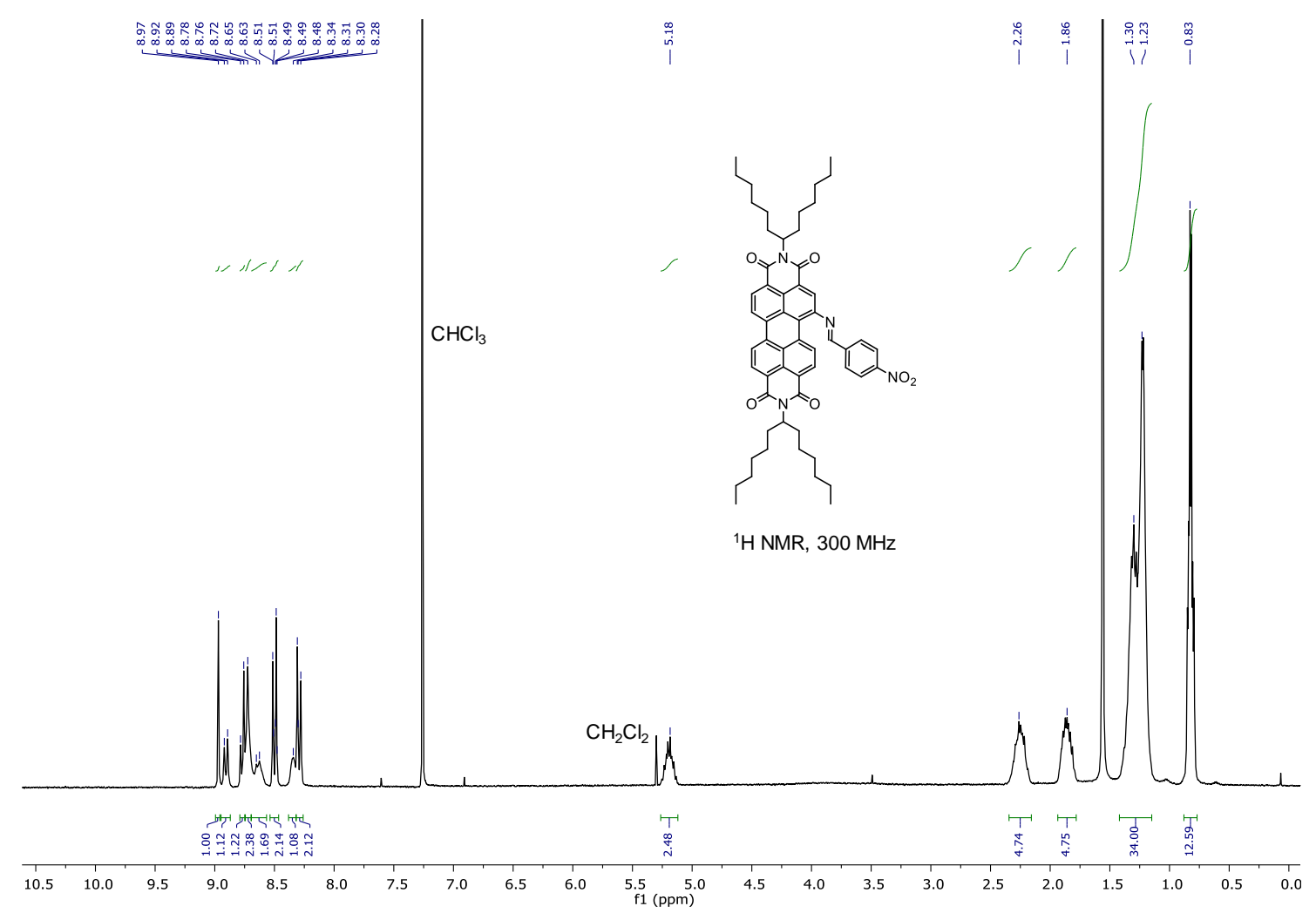

Figure S18. ${ }^{1} \mathrm{H}$ NMR spectrum of compound $3 \mathbf{i}$ in $\mathrm{CDCl}_{3}$ at $298 \mathrm{~K}$.

\section{Mass Spectrometry}

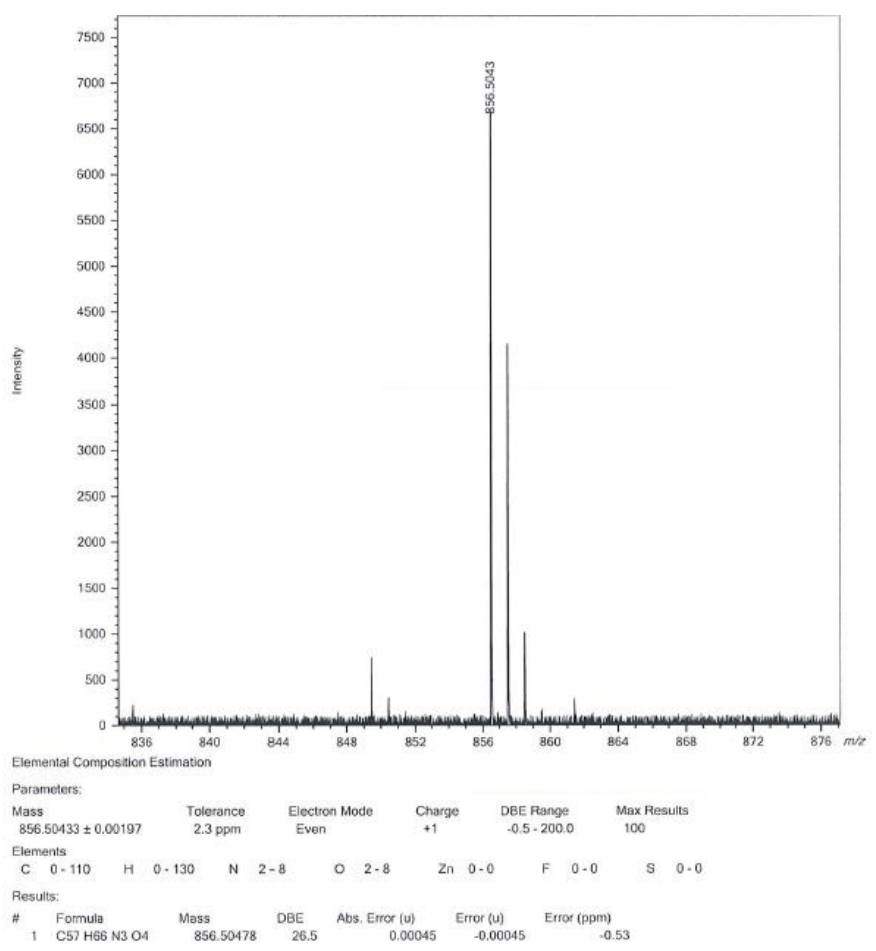

Figure S19. HRMS spectrum of compound $\mathbf{1 .}$ 


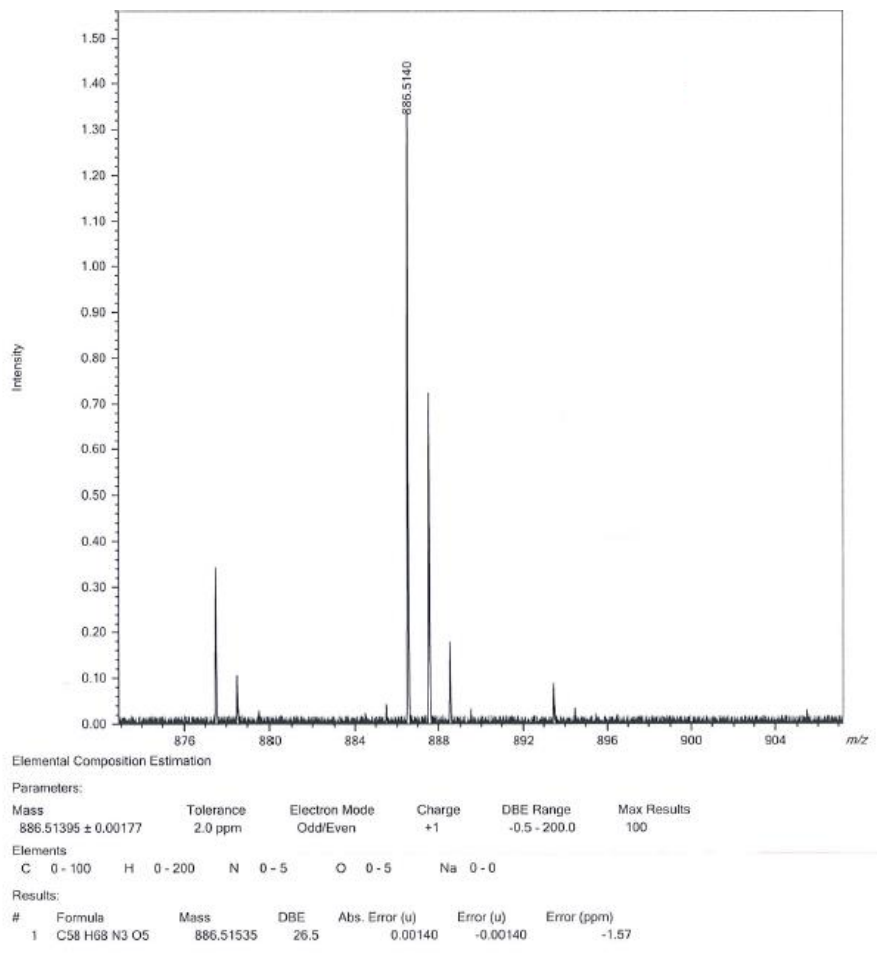

Figure S20. HRMS spectrum of compound 2.

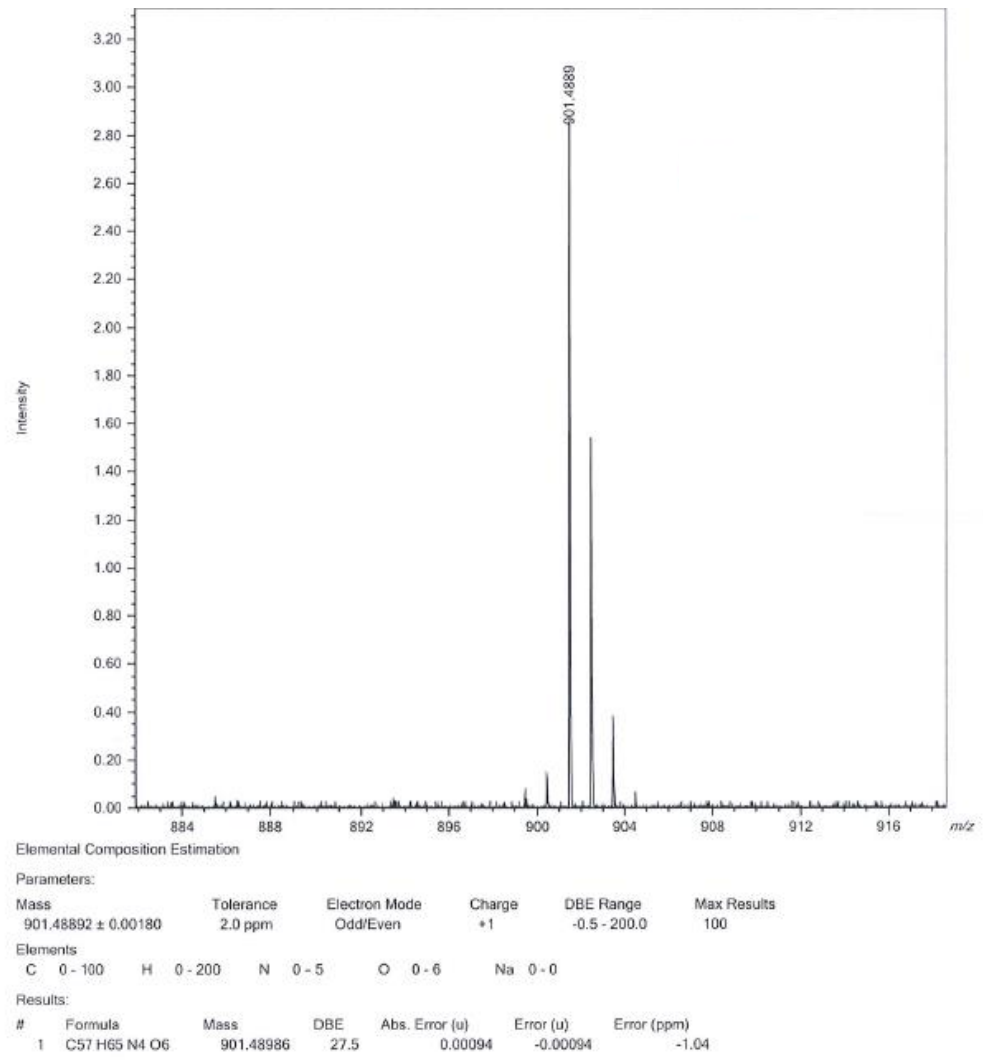

Figure S21. HRMS spectrum of compound 3. 


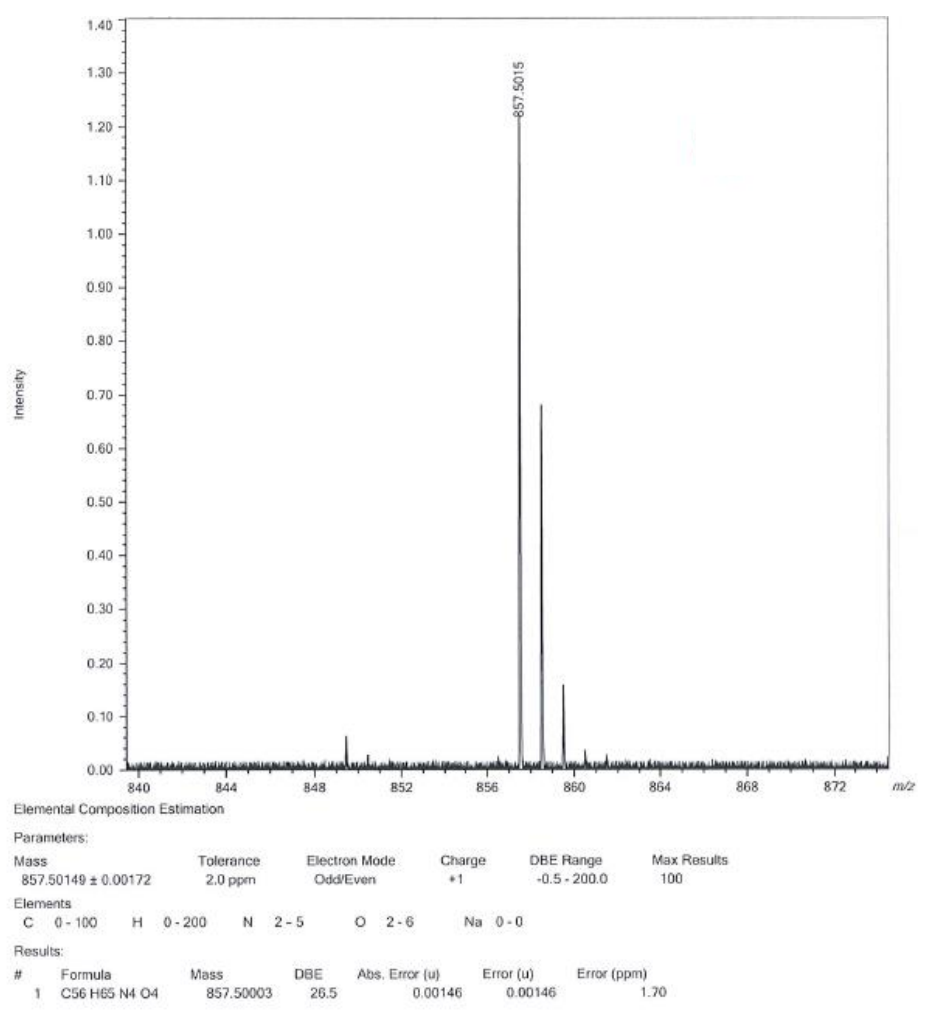

Figure S22. HRMS spectrum of compound 4.

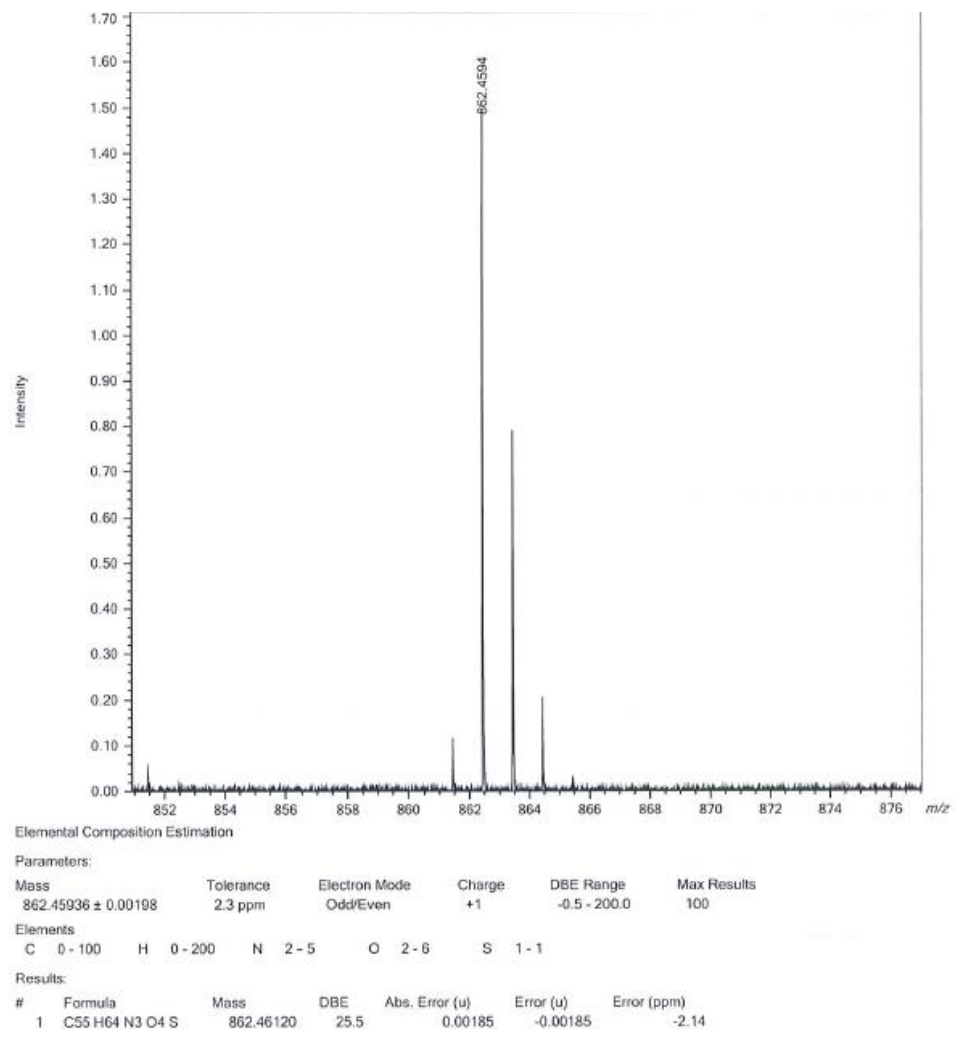

Figure S23. HRMS spectrum of compound 5. 


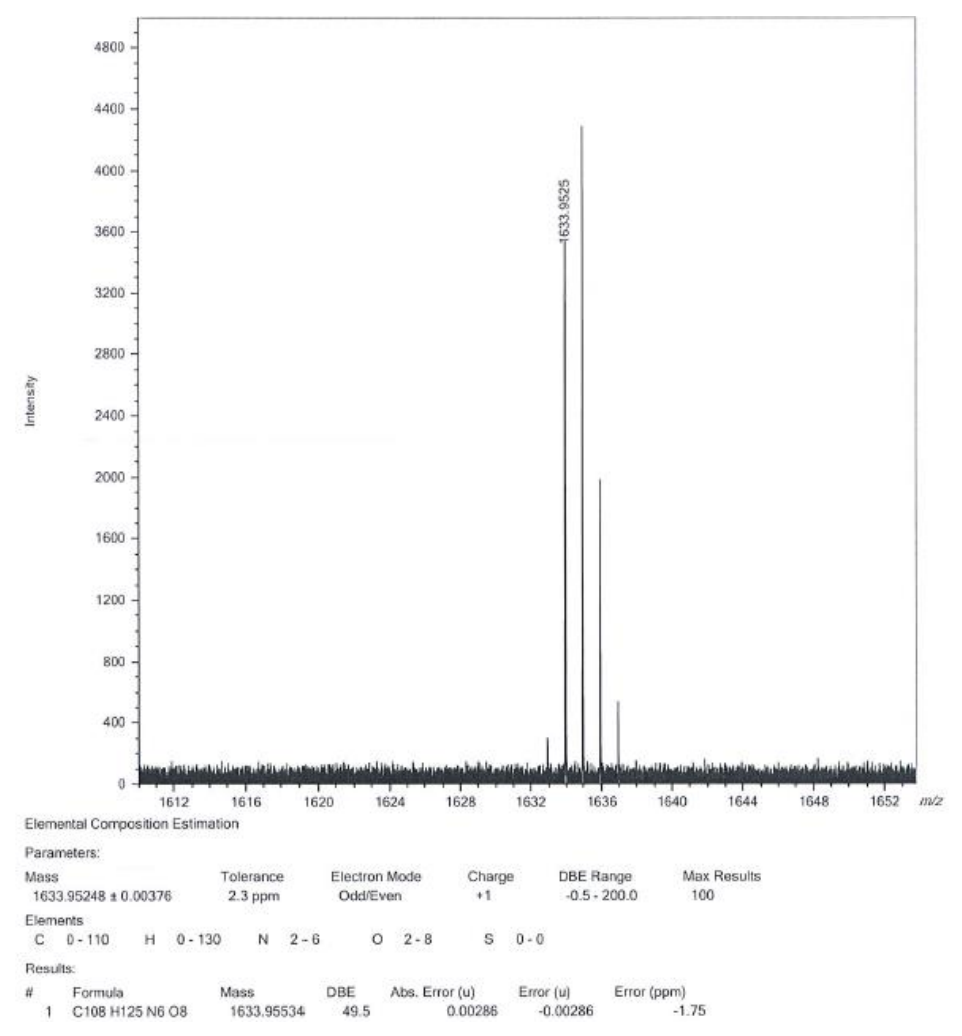

Figure S24. HRMS spectrum of compound 6.

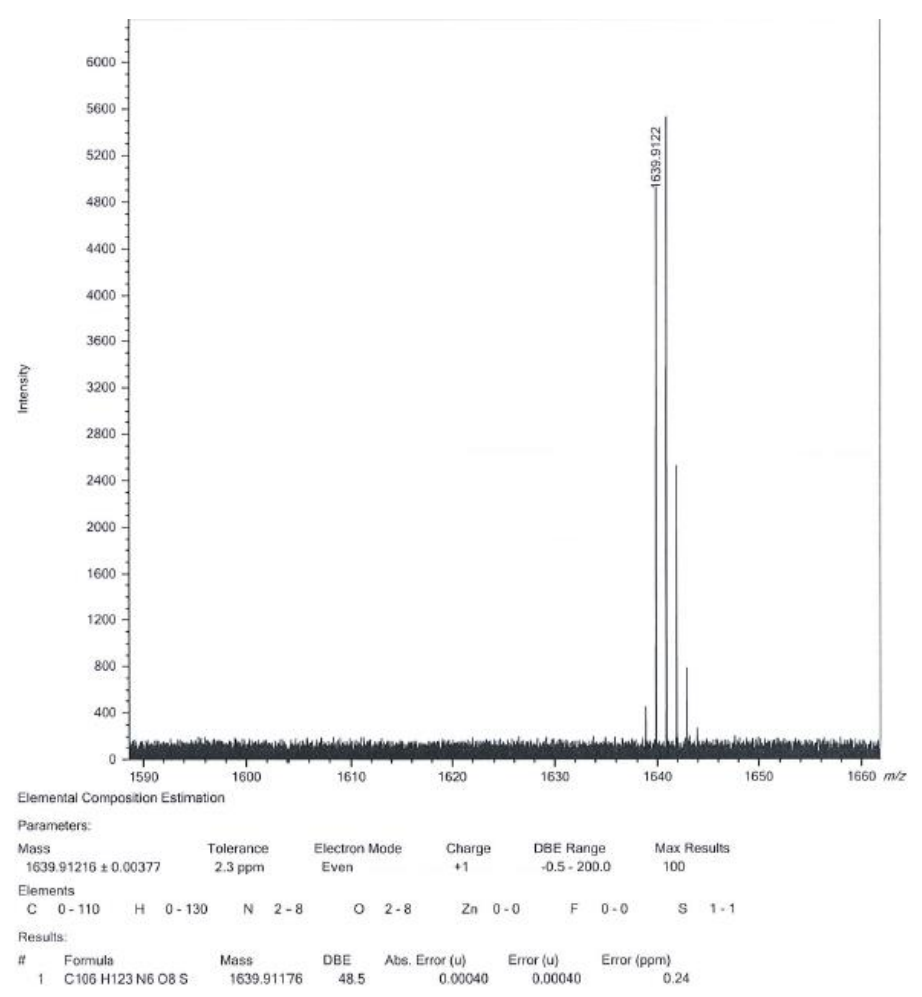

Figure S25. HRMS spectrum of compound 7. 


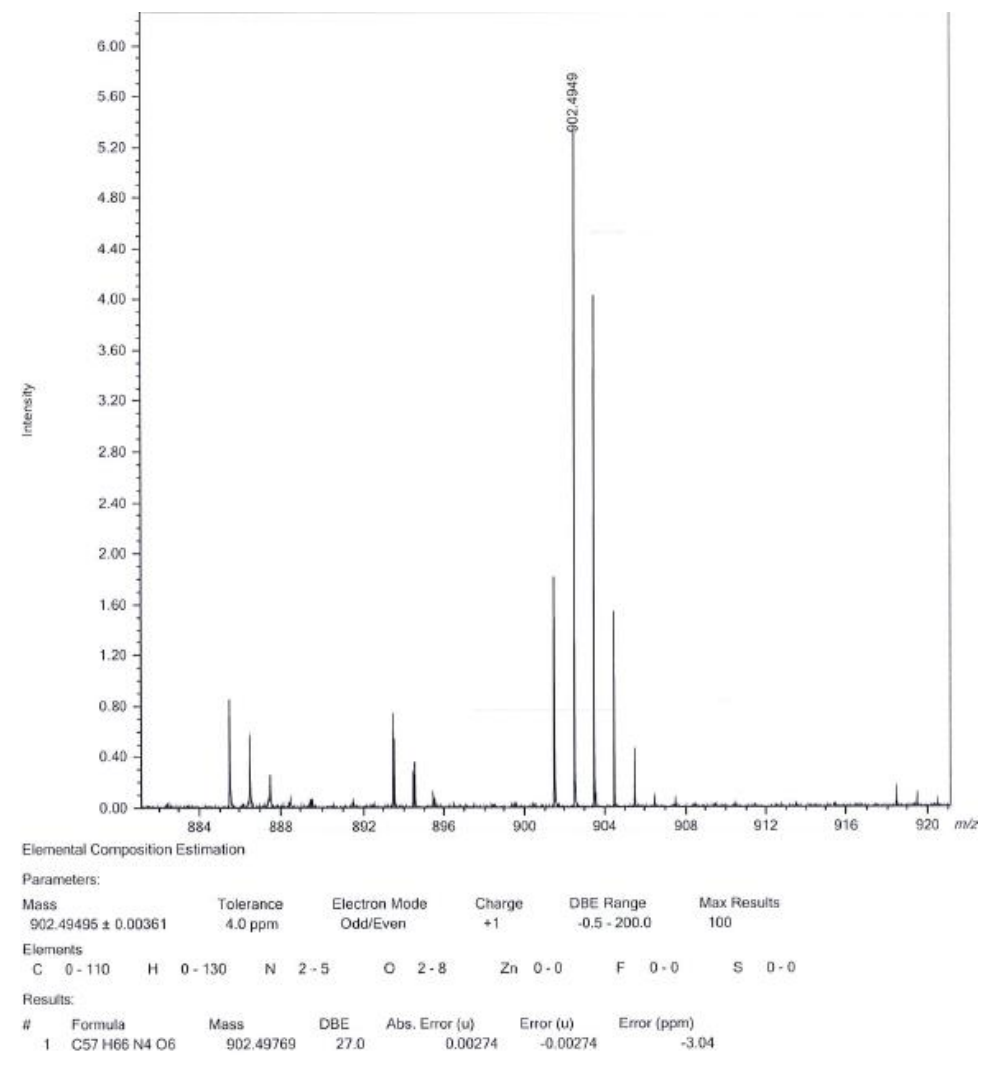

Figure S26. HRMS spectrum of compound 3i. 